\title{
Performance Between PFC Cuk and Bridgeless PFC Cuk Converter with Various Output Voltages
}

\author{
N.A.A. Isa, W.M. Utomo, M. K. R. Noor, M.A.Z.A. Rashid, A.F.H.A. Gani, A.A. Bakar, S.S. Yi, \\ Iradiatu Diah P K
}

\begin{abstract}
This paper presents about the comparison between single-phase PFC Cuk converter and bridgeless PFC (BPFC) Cuk converter for low power application. This study attempts to investigate the characteristics of conventional and bridgeless PFC Cuk converter structures with three different output voltages and verified by the simulation results. The BPFC Cuk converter provides a lower Total Harmonic Distortion (THD) of input current than the conventional PFC Cuk converter. However, the conventional PFC Cuk converter has advantage of less maximum current stress at components compared to the BPFC Cuk converter. Conventional and BPFC Cuk converter can achieve an approximately unity power factor $(P F)$.
\end{abstract}

Indes Terms: single-switch, conventional, bridgeless, power factor correction, Cuk converter.

\section{INTRODUCTION}

The power electronic equipment with an active power factor correction (pfc) has becoming important especially for telecom, datacom, and automotive electrical system [1][2][3][4]. Most of power electronic supply with switch mode are used to convert ac to dc voltage [5]. Therefore, transformer and full bridge rectifier able to realize output dc voltage simply, but the input current will be affected [5]. When the bridge rectifier is connected with the non-linear load or non-linear device, the pf is poor and thd is high. Thus, the full-bridge rectifier requires pfc such as dc-dc converters as a passive pfc.

Several types of DC-DC PFC converters were developed for PFC applications such as boost, buck, buck-boost, SEPIC and Cuk converters [6]. The most popular topology for PFC converter is boost converter [7]. Unfortunately,

Revised Manuscript Received on June 22, 2019.

N. A. A. Isa, Department of Electrical Power Engineering (JEK), Faculty of Electrical and Electronics Engineering (FKEE),Universiti Tun Hussein Onn Malaysia, Johor, Malaysia

W. M. Utomo, Department of Electrical Power Engineering (JEK), Faculty of Electrical and Electronics Engineering (FKEE),Universiti Tun Hussein Onn Malaysia, Johor, Malaysia

M. K. R. Noor, Department of Electrical Power Engineering (JEK) Faculty of Electrical and Electronics Engineering (FKEE),Universiti Tun Hussein Onn Malaysia, Johor, Malaysia

M. A. Z. A. Rashid, Department of Electrical Power Engineering (JEK), Faculty of Electrical and Electronics Engineering (FKEE), Universiti Tun Hussein Onn Malaysia, Johor, Malaysia

A. F. H. A. Gani, Department of Electrical Power Engineering (JEK), Faculty of Electrical and Electronics Engineering (FKEE), Universiti Tun Hussein Onn Malaysia, Johor, Malaysia

A. A. Bakar, Department of Electrical Power Engineering (JEK), Faculty of Electrical and Electronics Engineering (FKEE), Universiti Tun Hussein Onn Malaysia, Johor, Malaysia

S.S. Yi, Department of Electrical Power Engineering (JEK), Faculty of Electrical and Electronics Engineering (FKEE), Universiti Tun Hussein Onn Malaysia, Johor, Malaysia

Iradiatu Diah P K , Department of Electrical Engineering, Faculty of Engineering and Marine Science, Universitas Hang Tuah, Surabaya, Indonesia
The boost converter has drawback that is the output voltage is higher than the input voltage [8]. Thus, buck type converter is needed, but the discontinuous input current makes the buck converter becomes unstable when the output line voltage is higher than the input line voltage [5].

Buck converter is usually used for low power application, [9]. However, at the zero crossing of input line voltage, the line current is not able to follow the input voltage [10]. Additional passive filter is required at the input buck converter to filter the input current [8]. Pfc buck converter tends to have high thd of current and low pf. Therefore, pfo cuk converter is proposed to overcome these issues.

Cuk converter produces a negative polarity output and can act like buck-boost converter. The converter able to step-up and step-down the output voltage by controlling the duty cycle [11]. Cuk converter has advantage for pfc application which are, easy to implement in transformer isolation, natural defense against inrush current from start-up or overload current, low ripple of input current and less electromagnetic interference associated with the $\mathrm{dcm}$ topologies [5][12][13]. The limit of the dcm operation of the cuk converter only in low-power applications [14].

A conventional pfc converter has low efficiency in term of thd of input current compared to the bpfc converter due to significant losses at the full bridge diodes [15]. In order to overcome the drawback of the conventional pfc converter, a bpfc converter is introduced [15]. The bpfc converter allows the current to flow through a minimum number of switching devices. Hence, the converter able to achieve low thd of input current.

The remainder of this study is systematized as follows: mode operation of conventional cuk converter will be shown in section ii. Then mode operation for bpfc cuk converter presented in section iii. Section iv discusses about the simulation result and analysis, followed by conclusion in section $\mathrm{v}$.

\section{MODE OPERATION OF CONVENTIONAL PFC CUK CONVERTER}

Conventional PFC Cuk converter structure has full bridge diodes at the input supply, but the bridgeless structure eliminates the diode bridge at the input supply. Both structures operate with positive and negative cycle Conventional PFC Cuk converter consists 6 mode operation while bridgeless PFC Cuk converter has 12 modes operation.

Mode- 1 operates when the MOSFET $M$ is turned-on and $\mathrm{D}_{\mathrm{p}}$ also is on-state as shown in Fig. .Meanwhile, Mode2operates when the MOSFET $M$ is turned-off and $D_{n}$ are on-

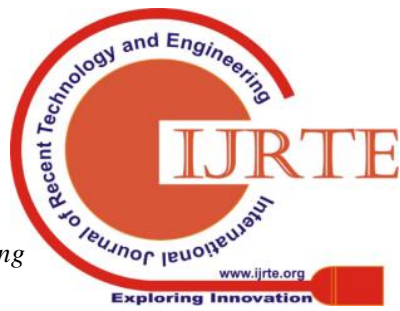


state as shown in Fig. In the mode-1 and mode-2, the energy from the AC source is stored in inductor $L_{\text {in }}$, capacitor $C_{\text {in }}$ is discharging to inductor $L_{\text {out }}$ and capacitor $C_{\text {out }}$ and the power is supplied to the loads.

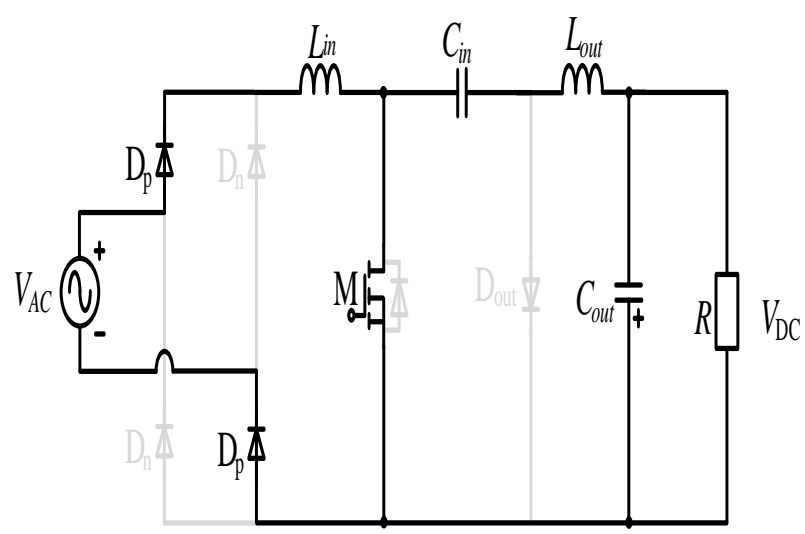

Fig. 1 Mode-1 operation of PFC cuk converter

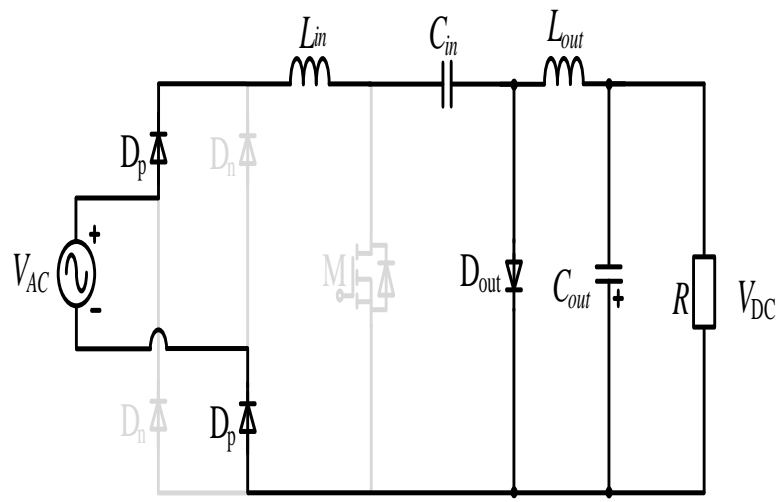

Fig. 2 Mode-2 operation of PFC cuk converter

Mode-3operates when the MOSFET $M$ is turned-off and $\mathrm{D}_{\mathrm{p}}$ are on-state as shown in Fig.Meanwhile, Mode-4operates when the MOSFET $M$ is turned-on and $D_{n}$ are on-state as shown in Fig. 4 . In the mode-3 and mode-4, the inductor $L_{\text {in }}$ recharges the capacitor $C_{i n}$, and inductor $L_{\text {out }}$ recharges the capacitor $C_{\text {out }}$ through the freewheeling diodes $\mathrm{D}_{\text {out }}$ and the power is supplied to the loads.

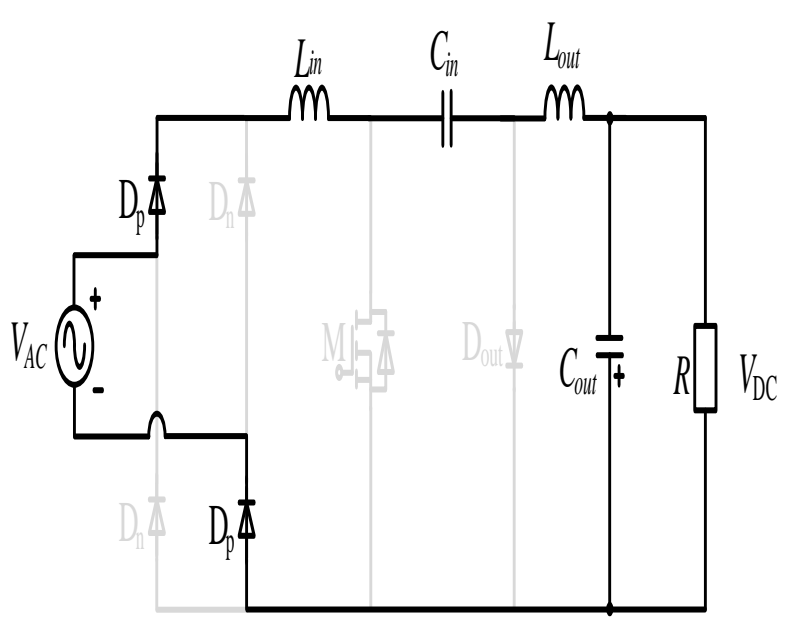

Fig. 3 Mode-3 operation of PFC cuk converter

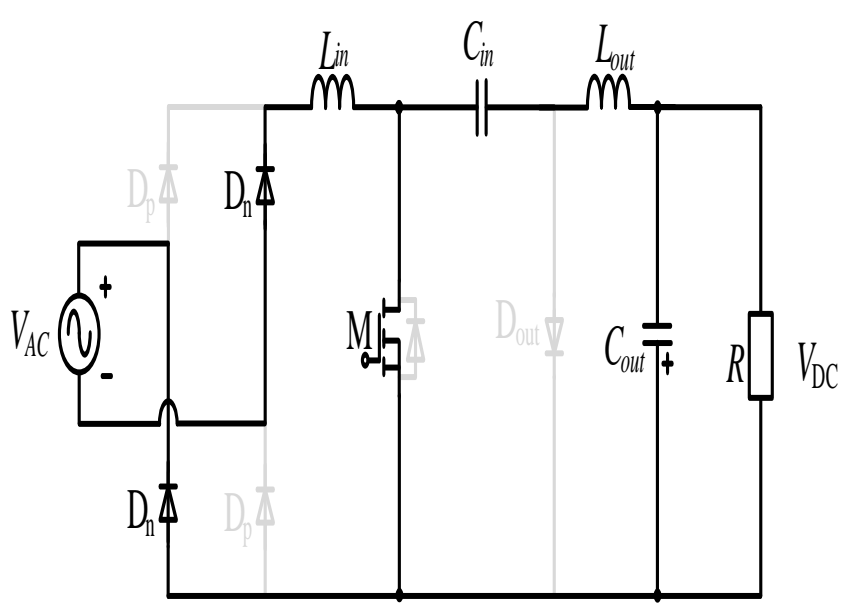

Fig. 4 Mode-4 operation of PFC cuk converter

Mode-5and mode 6 operates when the MOSFET $M$ is turned-off and $D_{n}$ are on-state as shown in Fig and Fig. In the mode-5 and mode-6, the capacitor $C_{\mathrm{in}}$ and inductor $L_{\text {out }}$ receive energy through the discharging of inductors $L_{\text {in }}$. The capacitor $C_{\text {out }}$ is discharging. During this interval, the diode $\mathrm{D}_{\text {out }}$ is turned-off and the power is supplied to the loads.

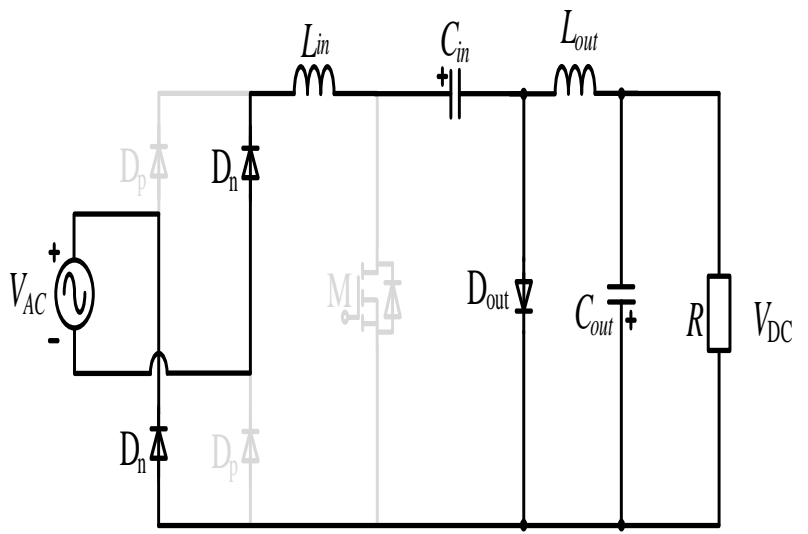

Fig. 5 Mode-5 operation of PFC cuk converter

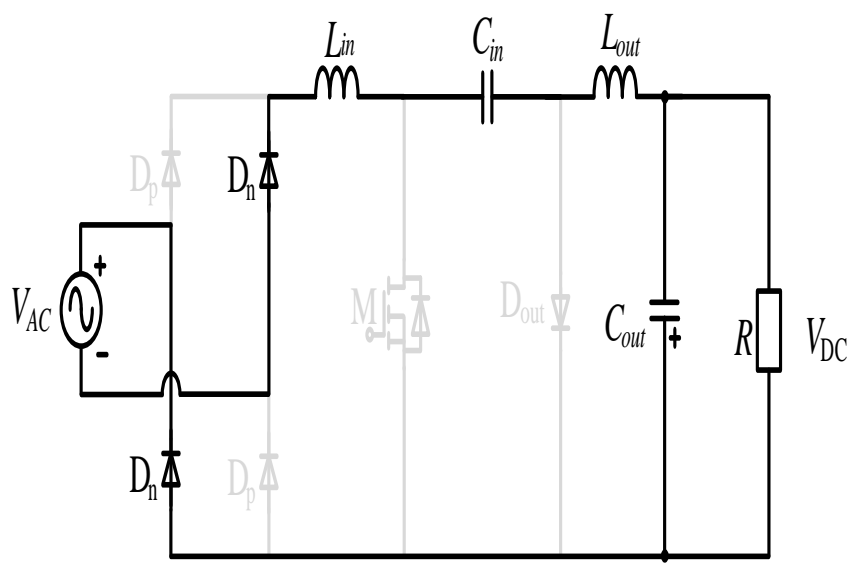

Fig. 6 Mode-6 operation of PFC cuk converter 


\section{MODE OPERATION OF BPFC CUK CONVERTER}

Mode-1 operates when the MOSFETM is turned-on, $D_{p}$, $D_{1}$ are on-state and $D_{\text {out }}$ is off-state as shown in Figure 7. There are two conditions in this operation mode. First, the inductors $L_{1}$ and $L_{2}$ are charging, the capacitor $C_{1}$ andcapacitor $C_{2}$ are discharging, the output inductor $L_{0}$ is charging and capacitor $C_{\text {out }}$ is discharging. In the second condition, capacitor $C_{1}$ andcapacitor $C_{2}$ are charging through inductors $L_{1}$ and $L_{1}$. Meanwhile, the inductor $L_{\text {out }}$ recharges the capacitor $C_{\text {out }}$.

Mode- 2 operates when the MOSFET $M$ is turned-on, $D_{n}$, $\mathrm{D}_{2}$ are on-state and $\mathrm{D}_{\text {out }}$ is off-state as shown in Fig. There are two conditions in this operation mode. First, the inductors $L_{1}$ and $L_{2}$ are charging, the capacitor $C_{1}$ andcapacitor $C_{2}$ are discharging, the output inductor $L_{\mathrm{o}} \mathrm{is}$ charging and capacitor $C_{\text {out }}$ is discharging. In the second condition, capacitor $C_{1}$ andcapacitor $C_{2}$ are charging through inductors $L_{1}$ and $L_{1}$. Meanwhile, the inductor $L_{\text {out }}$ recharges the capacitor $C_{\text {out }}$

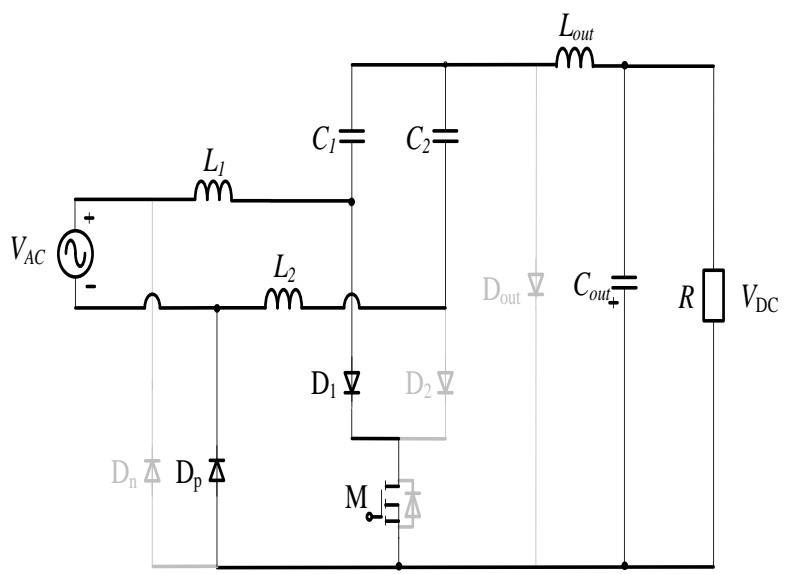

Fig. 7 Mode-1 operation of bridgeless PFC cuk converter



Fig. 8 Mode-2 operation of bridgeless PFC cuk converter

Mode-3 operates when the MOSFET $M$ is turned-off, $D_{p}$, is on-state and $D_{\text {out }}$ is on-state as shown in Fig. 9 . Mode 3 consists of four conditions operation modes. First, capacitor $C_{1}$ andcapacitor $C_{2}$ are charging while inductors $L_{1}$ and $L_{2}$ are discharging. At the same time, the output inductor $L_{\text {out }}$ is discharging, capacitor $C_{\mathrm{o}}$ is charging and the power is supplied to the load. Second, inductor $L_{1}$,inductor $L_{2}$ andcapacitor $C_{2}$ are discharging,while inductor
$L_{1}$, inductor $L_{2}$ andcapacitor $C_{2}$ are discharging, then capacitor $C_{1}$ is charging. Output inductor $L_{\text {out }}$ is discharging and capacitor $C_{\text {out }}$ is charging and the power is supplied to the load. Third, inductor $L_{1}$,inductor $L_{2}$ andcapacitor $C_{2}$ are discharging,while capacitor $C_{1}$ is charging. At the same time, capacitor $C_{\text {out }}$ is discharging through output inductor $L_{\text {out }}$ and the power is supplied to the load. Fourth, capacitor $C_{1}$ andcapacitor $C_{2}$ are discharging through inductors $L_{1}$ Meanwhile, $L_{2}$ is in charging mode. Output inductor $L_{\text {out }}$ recharges capacitor $C_{\text {out. }}$ and the power is supplied to the load.

Mode- 4 operates when the MOSFET $M$ is turned-off, $D_{n}$, is on-state and $\mathrm{D}_{\text {out }}$ is on-state as shown in Fig. First, capacitor $C_{1}$ andcapacitor $C_{2}$ are charging while inductors $L_{1}$ and $L_{2}$ are discharging. At the same time, the output inductor $L_{\text {out }}$ is discharging, capacitor $C_{\mathrm{o}}$ is charging and the power is supplied to the load. Second, inductor $L_{1}$,inductor $L_{2}$ andcapacitor $C_{2}$ are discharging,while inductor $L_{1}$, inductor $L_{2}$ andcapacitor $C_{2}$ are discharging,then capacitor $C_{1}$ is charging. Output inductor $L_{\text {out }}$ is discharging and capacitor $C_{\text {out }}$ is charging and power is supplied to the load. Third, inductor $L_{1}$,inductor $L_{2}$ andcapacitor $C_{2}$ are discharging,while capacitor $C_{1}$ is charging. At the same time, capacitor $C_{\text {out }}$ is discharging through output inductor $L_{\text {out }}$ and the power is supplied to the load. Fourth, capacitor $C_{1}$ andcapacitor $C_{2}$ are discharging through inductors $L_{1}$ Meanwhile, $L_{2}$ is in charging mode. Output inductor $L_{\text {out }}$ recharges the capacitor $C_{\text {out. }}$ and the power is supplied to the load.

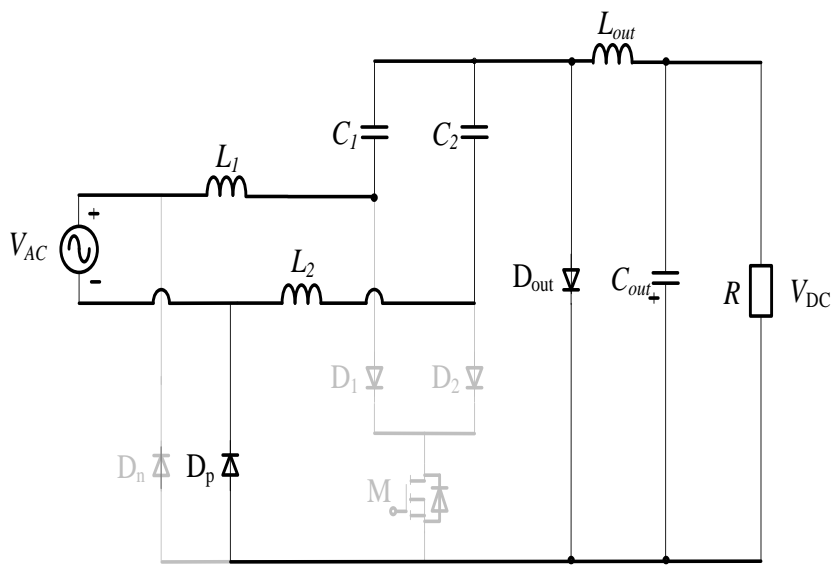

Fig. 9 Mode-3operation of bridgeless PFC cuk converter

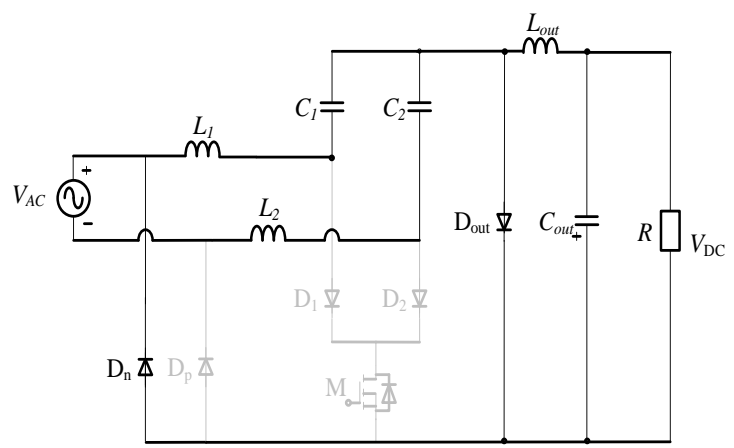

Fig. 10 Mode-4 operation of bridgeless PFC Cuk converter 


\section{SIMULATION RESULT}

The performance of single-switch conventional and BPFC Cuk converter is verified by the simulation results by using PLECS software. Both converters are designed by the following specifications:

- Input voltage, $\mathrm{V}_{\mathrm{AC}}=230 \mathrm{~V}$



- Output power, $\mathrm{P}_{\text {out }}=200 \mathrm{~W}$

- Switching frequency, $\mathrm{f}_{\mathrm{sw}}=50 \mathrm{~Hz}$

- Maximum output voltage ripple, $\Delta \mathrm{V}_{\text {out }}=<2 \mathrm{~V}$

\section{Power factor}

Since the conventional PFC Cuk and BPFC Cuk converter are PFC type converter, both of the converters are designed to achieve high power factor. Fig. and Fig show the current and voltage in single phase for both types of converters.

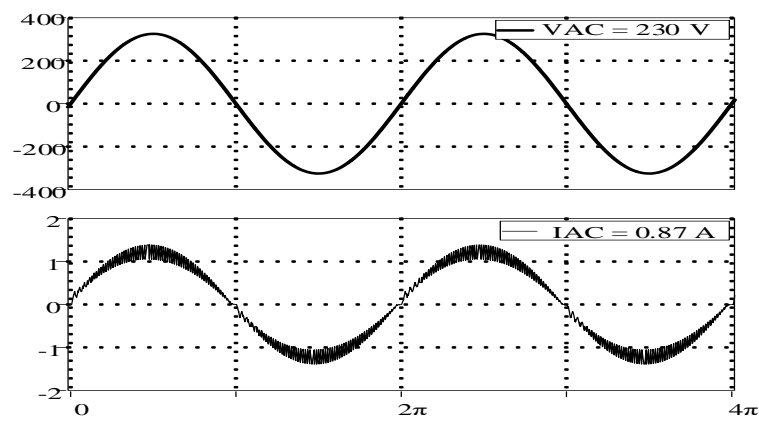

Fig. 11 Input waveform of conventional PFC Cuk

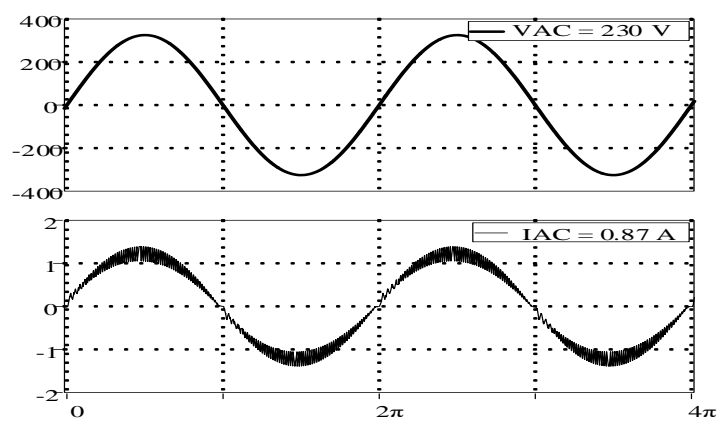

Fig. 12 Input waveform of BPFC Cuk

\section{Maximum current stress}

In this section, the maximum current stress at the components will be discussed with three differences value of output voltages. Power switch are used to open and close a circuit. When a circuit is opened, current flowing through the power switch is interrupted. So, low maximum current stress the MOSFET is required to avoid the switching losses and prevent MOSFET from damage.

Figure 13 and Figure 14 show the current waveform characteristics of voltage and current at MOSFET for conventional and BPFC Cuk converter. The BPFC Cuk converter has higher maximum current stress compared to the PFC Cuk converter. As when the the output voltage increases, the maximum current stress reduced.The result shows that the conventional PFC Cuk converter has less maximum current stress at the components compared to the BPFC Cuk converter.



Fig. 13 MOSFET voltage and current of conventional PFC Cuk, Vout $=-42 \mathrm{~V}$

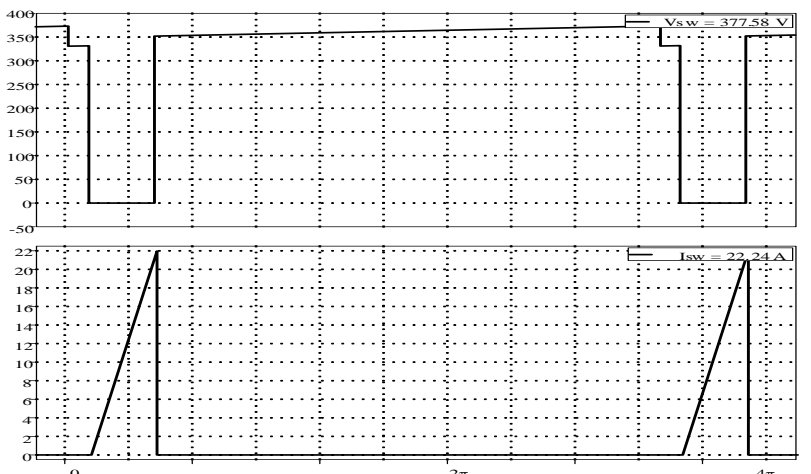

Fig. 14 MOSFET voltage and current of BPFC Cuk, Vout $=-42 \mathrm{~V}$

Figure 15 shows the current waveform of input and output diode for conventional PFC Cuk converter with -42 Vout while Figure 16 show the input and output diode with -42 Vout for BPFC Cuk converter. Different ouput voltage which are $-42 \mathrm{~V},-48 \mathrm{~V}$ and $-54 \mathrm{~V}$ demonstrate same maximum input diode current stress, such that the maximum input current diode for conventional PFC Cuk are 1.39 A and 1.66 A for BPFC Cuk converter. For the ouput diode, the maximum current stress will increase when the ouput voltage decreases as shown. Hence, it can be concluded that the BPFC Cuk converter has higher maximum current stress compared to the conventional PFC Cuk converter.
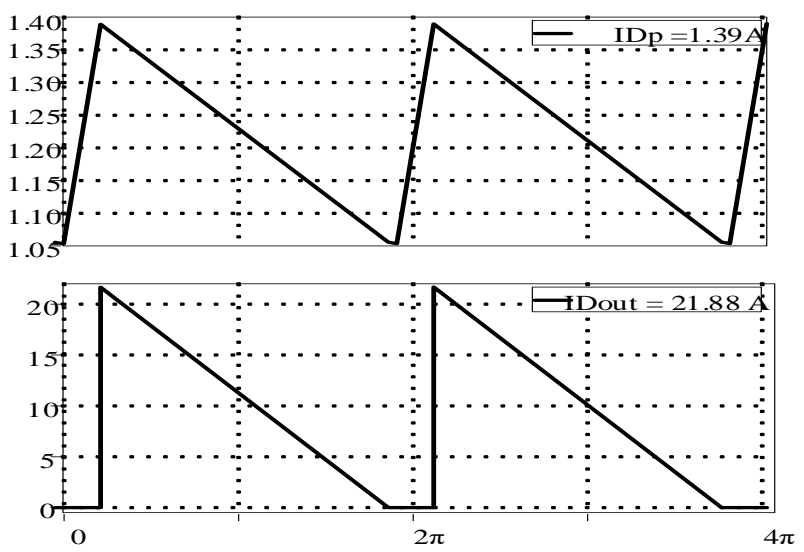

Fig. 15 Input and output diode current of conventional PFC Cuk 

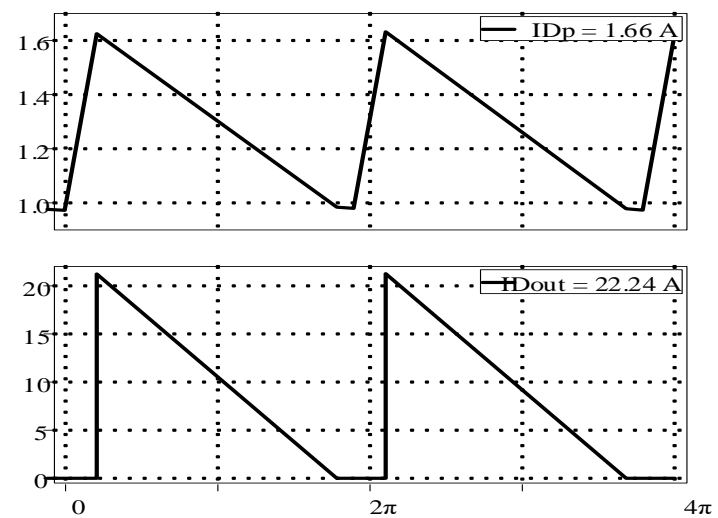

Fig. 16 Input and output diode current of BPFC Cuk

The current waveforms for input and output capacitor are shown in Figure 17 with -42 Vout. Meanwhile, Figure 18 shows the capacitor current waveform for $-42 \mathrm{~V}_{\text {out }}$ BPFC Cuk converter. The highest input capacitor maximum current stress which are -20.49 A for conventional PFC Cuk converter and -20.84 A for BPFC Cuk converter occurs when the output voltage is $-42 \mathrm{~V}$. However, the maximum current stress at output capacitor when the output voltage is $-42 \mathrm{~V}$ reduces to $15.73 \mathrm{~A}$ for conventional PFC Cuk converter and $15.92 \mathrm{~A}$ for BPFC Cuk converter. As the output voltage increases the maximum current at the capacitor will decrease.
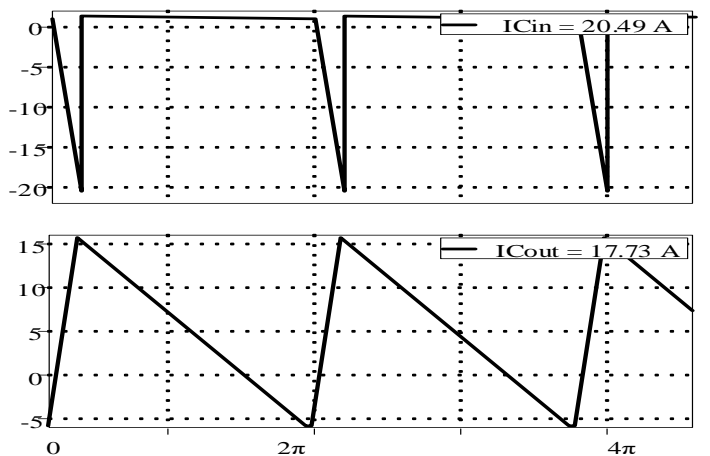

Fig. 17 Input and output capacitor current of conventional PFC Cuk


Fig. 18 Input and output capacitor current of BPFC Cuk

In order to store more energy in an inductor, the current through the inductor must be increased. This means that the strength of the magnetic field must increase and the change in field strength produces the corresponding voltage according to the principle of electromagnetic selfinduction.
The current waveforms for input and output inductor are illustrated in Figure 19 with -42 Vout. Meanwhile, Figure 20 shows the inductor current waveform for -42 Vout BPFC Cuk converter. The ouput inductor has low maximum current stress compared to the ouput capacitor for conventional PFC Cuk converter and BPFC Cuk converter. The -48 Vout has higher input inductor current which are $1.40 \mathrm{~A}$ for conventional PFC Cuk converter and $1.43 \mathrm{~A}$ for BPFC Cuk converter. Meanwhile, the $-42 \mathrm{~V}$ and $-54 \mathrm{~V}$ output voltages have the same value of input inductor current which is $1.39 \mathrm{~A}$ for conventional PFC Cuk converter and 1.42 A for BPFC Cuk converter. The output inductor current increases when the ouput voltage is decreased and the conventional PFC Cuk converter has lower input and output inductor current compared to the BPFC Cuk converter.
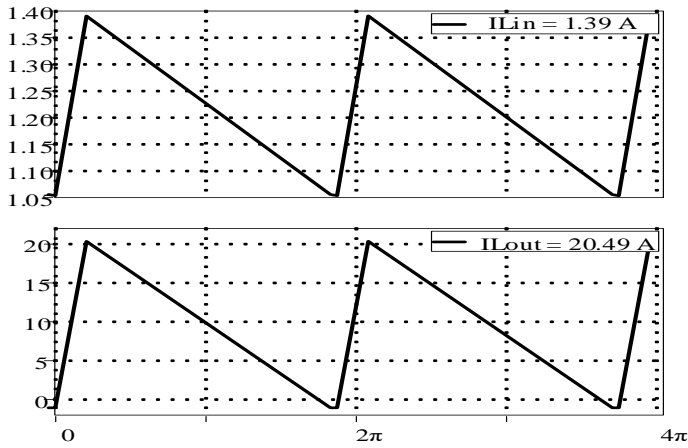

Fig. 19 Input and output inductor current of conventional PFC Cuk
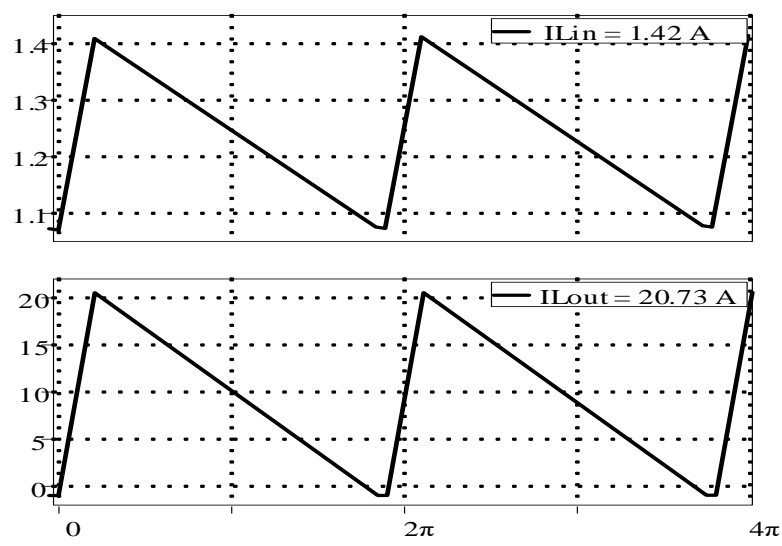

Fig. 20 Input and output inductor current of BPFC Cuk

\section{THD of input current}

Total harmonic distortion (THD) is an important aspect in power converter and should be kept as low as possible. High THD current will effect the PF and reduces the efficiency of converter.

The THD of the input current for the both converters is shown in Fig. The conventional PFC Cuk converter has high THD of input current than the BPFC Cuk converter. 


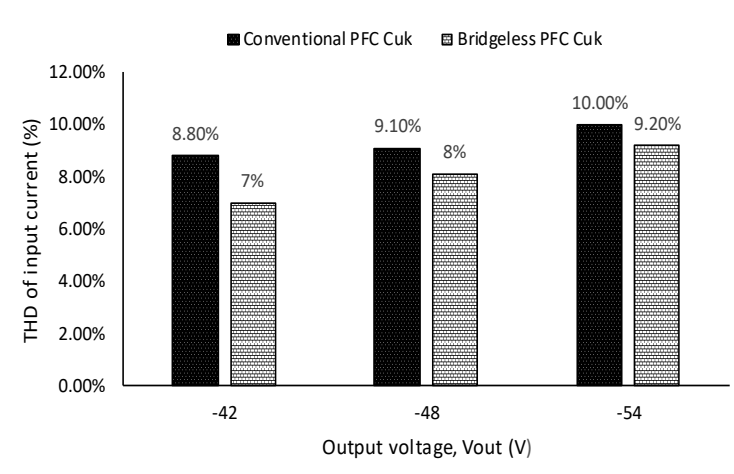

Fig. 21 Total harmonic distortion of the input current

\section{CONCLUSION}

In this paper, the comparison between single-switch conventional and BPFC Cuk converter has been presented and analyzed with $-42 \mathrm{~V},-48 \mathrm{~V}$ and $-54 \mathrm{~V}$ of output voltages. The simulation result shows BPFC Cuk converter has an advantage on less THD of input current compare to the conventional PFC Cuk converter. However in the BPFC the maximum current stress at the components is higher if to be compared to the conventional PFC Cuk converter. Maximum current stress on the components will decrease when the output voltage is increased. Both of the converters show a fair performance in PF and able to achieve 0.99.

\section{ACKNOWLEDGMENT}

The authors would like to express their deepest appreciation to the Ministry of Higher Education (MOHE) Malaysia and Universiti Tun Hussein Onn Malaysia for supporting this research withresearch fund, UTHM under Geran Penyelidikan Pascasiswazah (GPPS) Vot. H309 and Power Electronic Converters Focus Group (PEC), Department of Electrical Power Engineering, Faculty of Electrical and Electronic Engineering, UTHM to undertake this research activity.

\section{REFERENCES}

1. A. Fardoun, E. H. Ismail, M. A. Al-Saffar, and A. J. Sabzali, "New 'real' bridgeless high efficiency AC-DC converter," in Conference Proceedings - IEEE Applied Power Electronics Conference and Exposition - APEC, 2012, pp. 317-323.

2. H. Nene, C. Jiang, and S. Choudhury, "Control for Light Load Efficiency and THD Improvements in PFC Converter,” pp. 1785-1788, 2017.

3. Mangu and B. G. Fernandes, "Efficiency improvement of solar-wind based dual-input Cuk-SEPIC converter for telecom power supply," IECON Proc. (Industrial Electron. Conf., pp. 978-983, 2012.

4. K. C. Lee and B. H. Cho, "Low cost power factor correction (PFC) converter using delay control," Power Convers. Conf. - Nagaoka 1997. Proc., vol. 1, no. September, pp. 335-340 vol.1, 1997.

5. H. T. Yang, H. W. Chiang, and C. Y. Chen, "Implementation of Bridgeless Cuk Power Factor Corrector With Positive Output Voltage," IEEE Trans. Ind. Appl., vol. 51, no. 4, pp. 3325-3333, 2015.

6. H. Z. Azazi, S. M. Ahmed, and A. E. Lashine, "High power factor and regulated output voltage for three-phase AC-DC converter using single-mosfet CUK converter,” 2017 19th Int. Middle-East Power Syst. Conf. MEPCON 2017 - Proc., vol. 2018-Febru, no. December, pp. 43$51,2018$.

7. J. Sabzali, E. H. Ismail, M. A. Al-Saffar, and A. A. Fardoun, "A new bridgeless PFC Sepic and Cuk rectifiers with low conduction and switching losses," 2009 Int. Conf. Power Electron. Drive Syst., pp. 550-556, 2009.

8. M. Mahdavi, S. Member, and H. Farzanehfard, "Bridgeless SEPIC PFC Rectifier With Reduced Components and Conduction Losses," IEEE Trans. Ind. Electron., vol. 58, no. 9, pp. 4153-4160, 2011.
9. L. Huber, L. Gang, and M. M. Jovanovi, "Design-Oriented Analysis and Performance Evaluation of Buck PFC Front End," vol. 25, no. 1, pp. 85-94, 2010.

10. J. Liu, Y. Liu, Y. Zhuang, and C. Wang, "Analysis to input current zero crossing distortion of bridgeless rectifier operating under different power factors," Energies, vol. 11, no. 9, 2018.

11. M. K. R. Noor et al., "Optimization of PFC SEPIC Converter Parameters Design for Minimization of THD and Voltage Ripple," Int. J. Eng. Technol., vol. 7, no. 1, pp. 240-245, 2018.

12. S. L. Simonetti, J. Sebastian, and J. Uceda, "The discontinuous conduction mode Sepic and Cuk power factor preregulators: analysis and design," IEEE Trans. Ind. Electron., vol. 44, no. 5, pp. 630-637, 1997.

13. M. Brkovic and S. Cuk, "Input current shaper using Cuk converter," [Proceedings] Fourteenth Int. Telecommun. Energy Conf. - INTELEC '92, pp. 532-539, 1992.

14. R. Z. Detection, Y. Roh, Y. Moon, J. Gong, and C. Yoo, "Active Power Factor Correction ( PFC ) Circuit With," Power, vol. 26, no. 2, pp. 630-637, 2011.

15. A.A. Fardoun1, E. H. Ismail, A. J. Sabzali, and and M. A. Al-Saffar, "A Comparison between Three Proposed Bridgeless Cuk Rectifiers and Conventional Topology for Power Factor Correction,” 2010 IEEE Int. Conf. Sustain. Energy Technol., pp. 1-6, 2010. 